\title{
Functional interference between estrogen-related receptor alpha and peroxisome proliferator-activated receptor alpha/9-cis-retinoic acid receptor alpha heterodimer complex in the nuclear receptor response element-1 of the medium chain acyl-coenzyme A dehydrogenase gene
}

\author{
K Maehara, T Hida, Y Abe, A Koga, K Ota and E Kutoh \\ 4th Division of Frontier Science, Building 10, Tokyo R\&D Center, Daiichi Pharmaceutical Co. Ltd, 1-16-13, Kita-Kasai 1-Chome, Edogawa-Ku, Tokyo \\ 134-8630, Japan \\ (Requests for offprints should be addressed to E Kutoh, Department of Internal Medicine, Wajs Hospital, Ul. Bohaterow Wrzesnia 33, Sieradz, Poland; \\ Email: ekuto@ excite.com)
}

\begin{abstract}
We undertook a study of molecular interference of nuclear orphan receptors. Nuclear receptor response element-1 (NRRE-1) from the human medium-chain acyl coenzyme A dehydrogenase (MCAD) gene promoter was shown to contain three hexamer elements (site 1 through 3 ) that are known to interact with a number of nuclear receptors including chicken ovalbumin upstream promoter transcription factor (COUP-TF) and estrogen-related receptor alpha (ERR $\alpha)$. We demonstrated that the peroxisome proliferator-activated receptor alpha/9-cis-retinoic acid receptor alpha (PPAR $\alpha / R X R \alpha)$ heterodimer complex can also bind to the two hexamer repeat sequences (between site 1 and site 3 ) arranged as an everted imperfect repeat separated by $14 \mathrm{bp}$ (ER14). Mutations of the putative core elements have shown that these three sites are differentially involved in ERR $\alpha$ and PPAR $\alpha / R X R \alpha$ binding. Homodimer of $E R R \alpha$ was shown to interact between site 1 and site 3 (ER14). To date, no nuclear receptor is known to bind to response elements over such long intervals. Interestingly, site 1 was shown to be essential for ERR $\alpha$ binding while site 3 supports its binding only in the presence of site 1 . Furthermore, it was shown that the binding profile of ERR $\alpha$ and PPAR $\alpha / R X R \alpha$ are competitive rather than making a high order complex within NRRE-1. At the cellular level, transcriptional activation driven by the PPAR $\alpha / R X R \alpha$ complex was counteracted by the expression of ERR $\alpha$ in HeLa cells. These results suggest that ERR $\alpha$ and PPAR $\alpha / R X R \alpha$ could interfere with each other's function through binding to similar DNA elements, thereby finetuning the transcriptional outcome of the target gene. Our findings suggest a mechanism whereby multiple nuclear receptors can activate or repress DNA binding or transcription via a single pleiotropic regulatory element.
\end{abstract}

Journal of Molecular Endocrinology (2003) 31, 47-60

\section{Introduction}

The nuclear hormone receptors are a family of ligand-induced transcription factors that bind to specific DNA response elements and play crucial roles in a wide variety of cellular processes (excellent reviews are found in Mangelsdorf et al. 1995, Aranda \& Pascual 2001, Willson \& Moore 2002). Transcriptional regulation by nuclear hormone receptors involves participation of basal transcription factors, including TATA-binding protein and TFIIB, and other cofactors, known as nuclear transcriptional coactivators or corepressors, that form bridges between nuclear receptors and the basal transcription machinery (Polak 1997, Edwards 1999, Robyr et al. 2000). Many nuclear hormone receptors possess bimodal transcriptional properties and are capable of either repressing or 
activating target gene transcription, depending on the status of the ligand, the promoter and the nature of the host cell (Polak 1997, Gottlicher et al. 1998, Gay et al. 2002). In the absence of ligand, many receptors actively repress transcription via direct interactions with co-repressors such as SMRT (silencing mediator for retinoid and thyroid receptors), N-CoR (nuclear HDAC) or Sin3A (Rosenfeld \& Glass 2001). Upon ligand binding, these co-repressor complexes dissociate and the agonist-bound receptors interact with multiprotein coactivator complexes that contribute to the transmission of activating signals to the general transcription machinery. It is hypothesized that the ability of this complex to deacetylate histones results in an altered chromatin state that is inhibitory to transcription (Rosenfeld \& Glass 2001, Hsiao et al. 2003).

The nuclear receptors bind either as monomers or as homo- or heterodimers to response elements composed of a single core motif A/GGGTCA or to direct, palindromic or inverted repeats of the core motif spaced by one or more nucleotides (Forman \& Evans 1995, Khorasanizadeh \& Rastinejad 2001). Target gene recognition is specified by the DNA binding domain (DBD) which is composed of two zinc finger motifs that fold into two helical domains and a third helix extending from the second zinc finger (Freedman \& Luisi 1993). Response elements for these receptors generally consist of paired hexamer sites that bind receptor homo- or heterodimers, with specificity determined, at least in part, by the relative orientation and spacing of hexamers (Forman \& Evans 1995, Khorasanizadeh \& Rastinejad 2001). However, some members of these receptors are known to bind to the single hexamer sites as monomers (Kutoh et al. 2000, Lee \& Moore 2002).

The estrogen-related receptor $\alpha(\mathrm{ERR} \alpha)$ is an orphan member of the nuclear hormone receptor superfamily. A cDNA encoding this protein was originally isolated on the basis of sequence homology in its DNA-binding domain with estrogen receptor $\alpha$ (ER $\alpha$, Giguere et al. 1988, Giguere 2002). While ERR $\alpha$ displays significant homology to the estrogen receptor, it does not bind estrogens in vitro nor is its transcriptional activity modulated by estrogens (Yang et al. 1996). ERR $\alpha$ binds as a monomer to the extended halfsite TNAAGGTGA (core element underlined; Johnston et al. 1997, Sladek et al. 1997, Vanacker et al. 1998) or as a heterodimer or homodimer to the consensus estrogen response element (Pettersson et al. 1996, Vanacker et al. 1999). In the adult mouse, ERR $\alpha$ is most highly expressed in kidney, heart, and brown and white adipocytestissues which preferentially metabolize fatty acids and show a high capacity of fatty acid $\beta$-oxidation. These results suggest that ERR $\alpha$ may play a role in determining the metabolic potential of these tissues. ERR $\alpha$ was shown to interact with the nuclear receptor response element-1 (NRRE-1) of the medium-chain acyl coenzyme A dehydrogenase (MCAD) gene that is the key enzyme of the mitochondrial fatty acid $\beta$-oxidation cycle (Vega \& Kelly 1997). Given this background, ERR $\alpha$ appears to play a role in lipid metabolism. The transcriptional property of ERR $\alpha$ is still controversial. ERR $\alpha$ has been shown to have no effect or to repress transcription of the MCAD gene (Sladek et al. 1997) and SV40 major promoter (Wiley et al. 1993, Johnston et al. 1997). However, ERR $\alpha$ was also reported to activate transcription through the SFRE in a cell-specific manner (Bonnelye et al. 1997, Vanacker et al. 1999).

Peroxisome proliferator-activated receptors (PPARs) are also members of the nuclear hormone receptor superfamily. Their ligand-activated transcription factors respond to a class of chemical agents termed peroxisome proliferators that include the fibrate family of hyperlipidemia drugs, phthalate ester plasticizers, herbicides, pesticides, antidiabetic thiazolidinediones as well as certain fatty acids (reviewed by Takahashi \& Kawada 2001). PPARs heterodimerize with the 9-cis-retinoic acid receptor, $\operatorname{RXR} \alpha$, and bind to specific peroxisome proliferator-response elements (PPREs) found up-stream of target genes. PPREs have been identified in the promoter region of a number of genes involved in fatty acid metabolism. PPREs consists of a direct repeat of the hexameric motif TGACG(T/C) separated by one nucleotide (referred to as DR1), and serve to bind not only PPARs but also several other nuclear hormone receptors that differentially modulate PPAR function. Nuclear hormone receptors shown to modulate PPAR function include chicken ovalbumin upstream promoter transcription factor (COUP-TF) (Miyata et al. 1993), hepatocyte nuclear factor-4 (Winrow et al. 1994), TR (Hunter et al. 1996), LXR $\alpha$ (Miyata et al. 1996), and RZR $\alpha$ (Winrow et al. 1998). Therefore, transcriptional 
regulation from PPREs is a net aggregate response generated, in part, by the availability of PPARs and other factors that bind PPREs, the complexity of response elements, and the interplay of PPARs with other nuclear hormone receptors and cofactors, including corepressors and coactivators. This complex interaction of various factors and elements ensures that the correct transcriptional response to extra- and intracellular stimuli will be elicited from appropriate target genes.

In this study, we studied the interference of DNA binding and transcriptional properties of ERR $\alpha$ and PPAR $\alpha / R X R \alpha$ within the NRRE-1 from the human MCAD gene. Our findings suggest a mechanism whereby multiple nuclear receptors can activate or repress transcription via a single pleiotropic element.

\section{Materials and methods}

All buffers and solutions were prepared and standard molecular biology techniques were used as described in Sambrook et al. (1989).

\section{Plasmid constructs}

Rat PPAR $\alpha$, human RXR $\alpha$, mouse ERR $\alpha$ expression vectors (Ijpenberg et al. 1997, Sladek et al. 1997, Kassam et al. 1999, kind gifts from Drs Rachubinski and Giguere) were used for in vitro expression in reticulocyte lysate and transfection assays. For NRRE1/pBLCAT2 reporter plasmid, double stranded NRRE-1 wild-type (WT) as well as mutated (M) oligonucelotides designed to carry the HindIII (5') and BamHI $\left(3^{\prime}\right)$ restriction sites at each end were subcloned into the HindIII/BamHI sites present upstream of the thymidine kinase (TK) promoter of the pBLCAT2 plasmid (Luckow \& Schutz 1987). These plasmid DNAs were prepared using Qiagen EndoFree columns (Qiagen, Düsseldorf, Germany) for subsequent transfection experiments.

\section{In vitro transcription/translations}

Transcription/translation of cDNAs encoding PPAR $\alpha$, RXR $\alpha$ and ERR $\alpha$ was performed using the TNT T7-coupled rabbit reticulocyte lysate system according to the manufacturer's protocol
(Promega, Madison, WI, USA). Synthesized proteins were used for gel retardation assays.

\section{Oligonucleotides}

The following complementary synthetic oligonucleotides including the original flanking sequences were synthesized (Hitachi, Kawagoe, Japan), annealed and used for the gel retardation assay. One pmol of each double-stranded oligonucleotide was labeled with $\left[{ }^{32} \mathrm{P}\right] \mathrm{dGTP}$ (Amersham, Amersham, Bucks, UK) using Kenow DNA polymerase (Takara, Kyoto, Japan), and purified with a Nick column (Pharmacia, Uppsala, Sweden). A fill-in reaction was performed by adding the HindIII (5' end) and BamHI (3' end) at each end. The radiolabeled probes were used for gel retardation assays. Sequences of the sense strands of the annealed oligonucleotides are shown below. Consensus sequences are underlined. Mutations are shown with bold, small letters.

NRRE1WT: GGGTTTGACGTTTCTCTCG GGGTAA AGGTGAAGG; NRRE1 M1: GGGT TTGcttTTTCTCTCGGGGTAA AGGTGAAGG; NRRE1 M2: GGGTTTGACGTTTCTGTCGG ttcAA AGGTGAAGG; NRRE1 M3: GGGTT TGACATTTGTCTCGGGGTAA AttcGAAGG; NRRE1 M4: GGGTTTGcttTTTCTCTCGGttc AA AGGTGAAGG; NRRE1 M5: GGGTT TGett TTTCTCTCGGGGTAA AttcGAAGG; NRRE1 M6: GGGTTTGACGTTTCTCTCGG ttcAA AttcGAAGG; SFRE: AGGTAGGTGA AGGTGATG; AoxPPRE: AGGTTAACGTGAC GTTTGTCGTGGTGG; Histone H2B octamer: GTTCACGTTATTTGCATAAGGG.

\section{Gel retardation assays}

In vitro synthesized proteins in reticulocyte lysates as above were prepared and the gel retardation assays were performed as described previously (Kutoh et al. 1992). Briefly, binding reactions of $20 \mu \mathrm{l}$ were carried out in buffer containing $10 \mathrm{mM}$ Hepes (pH 7.9), $2.5 \mathrm{mM} \mathrm{MgCl}_{2}, 10 \%$ glycerol (v/v), $1 \mathrm{mM}$ dithiothreitol, $1 \mu \mathrm{g}$ poly $(\mathrm{dl}-\mathrm{dC}), 50 \mathrm{mM}$ $\mathrm{KCl}$, 2.5 fmol ${ }^{32}$ P-labeled oligonucleotides and $1 \mu \mathrm{l}$ reticulocyte lysate. Competitors (unlabeled probes) were added at the same time as the radiolabeled probes. Incubation was carried out at room temperature for $15 \mathrm{~min}$. Free and bound DNA were separated by electrophoresis on 
non-denaturing 4\% polyacrylamide gels (acrylamide bis 29:1, cross linked) with $0.5 \times \mathrm{TBE}$ $(1 \times$ TBE: $90 \mathrm{mM}$ Tris-borate, $1 \mathrm{mM}$ EDTA $)$ as running buffer. The gels were dried and analyzed by autoradiography. For some experiments, intensities of the signal were quantified using Adobe Photoshop 5.0 image analyzing software (Vero Beach, FI, USA).

\section{Cell culture, transfection and reporter gene assays}

HeLa cells (purchased from ATCG, Manassan, VA, USA and RIKEN, Tsukuba, Japan) were cultured in Dulbecco's modified Eagle's medium (DMEM, Life Technologies). The medium was supplemented with sodium bicarbonate $50 \mathrm{mM}$, penicillin $100 \mathrm{U} / \mathrm{ml}$, streptomycin $50 \mu \mathrm{g} / \mathrm{ml}$ and $10 \%$ fetal calf serum (FCS) and the cells were grown in a 95\% air/ $5 \% \mathrm{CO}_{2}$ atmosphere at $37^{\circ} \mathrm{C}$. Ten micrograms of each CAT reporter plasmid together with varying amounts of expression vector (ERR $\alpha$, PPAR $\alpha$ and $\operatorname{RXR} \alpha$ ) and $1 \mu \mathrm{g}$ of the $\beta$-galactosidase (pSV- $\beta$ gal, Promega, Madison, WI, USA) plasmid were transfected using the calcium phosphate transfection method (Protocols and Application Guide, Promega). The cells were harvested $48 \mathrm{~h}$ after the transfection and the CAT was measured using a CAT ELISA kit (Roche Diagnostics, Basel, Switzerland). To check the transfection efficiency, $\beta$-gal activities were measured with a $\beta$-gal ELISA kit (Roche Diagnostics).

\section{Preparation of RNA and RT-PCR}

Total RNAs of the transfected cells were prepared using Trizol reagent according to the manufacturer's protocol (Life Technologies, Paisley, Scotland). One microgram RNA was reverse-transcribed by $500 \mathrm{ng}$ oligo-dT primer, $1 \mu \mathrm{l} 10 \mathrm{mM}$ dNTPs and 200 units of SuperScript II reverse transcriptase (all from Life Technologies) in a total volume of $20 \mu \mathrm{l}$ according to the manufacturer's protocol. After the reaction, the mixture was heated at $65{ }^{\circ} \mathrm{C}$ for 10 min and $80 \mu \mathrm{l} \mathrm{H}_{2} \mathrm{O}$ were added. Subsequently, PCR reactions were performed in a total volume of $100 \mu \mathrm{l}$ containing $3 \mu \mathrm{l} \mathrm{cDNA}, 1 \mu \mathrm{l}$ of $20 \mathrm{mM}$ of each specific ERR $\alpha$ primers, $1 \mu \mathrm{l}$ of $10 \mathrm{mM}$ dNTPs and $2.5 \mathrm{U}$ Ex-Taq DNA polymerase (Takara, Kyoto, Japan). site 1

site2 site3

NRRE-1WT:

M1:

M2:

M3:

M4:

M5:

M6:

GGGTTTGACCTTTCTCTCCGGGTAAAGGTGAAGG GGGTT FettTTTCTCTCCGGGTAAAGGTGAAGG GGGTTTGACCTTTCTCTCCGHteAAAGGTGAAGG GGGTTTGACCTTTCTCTCCGGGTAAAtteGAAGG GGGTTTGettTTTCTCTCCGtteAAAGGTGAAGG GGGTTTGettTTTCTCTCCGGGTAAAtteGAAGG GGGTTTGACCTTTCTCTCCGtteAAAttcGAAGG

sitel

site2 site3

NRRE-1WT:

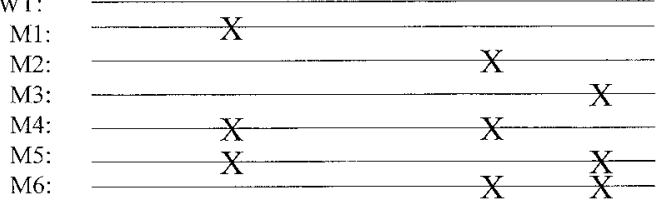

Figure 1 Consensus and mutational sequence of NRRE-1 from the human MCAD gene. The core hexamer elements are underlined and the mutations are shown with small, bold letters. In the bottom panel, mutations within the potential half-binding sites (site 1 through site 3 ) are shown with an X.

PCR primers used were $-\mathrm{ERR} \alpha$ forward: ATAACTCGAAGCAGGCTCGA; ERR $\alpha$ reverse: CAAAAGGGGTTTGTCTTTGG. For control, glyceraldehyde phosphate dehydrogenase (GA, Kutoh et al. 1998) specific primers were used.

After an initial denaturation at $93{ }^{\circ} \mathrm{C}$ for $2 \mathrm{~min}$, PGR was carried out in 30 cycles (from step 1 to step 3) using Gene Amp 9700 (Perkin Elmer, Norwalk, CT, USA) as follows: step 1: $93{ }^{\circ} \mathrm{C}$ for $1 \mathrm{~min}$ (denaturation); step 2: $60{ }^{\circ} \mathrm{C}$ for $1 \mathrm{~min}$ (annealing); step 3: $72{ }^{\circ} \mathrm{C}$ for 2 min (reaction); step 4: $72{ }^{\circ} \mathrm{C}$ for $7 \mathrm{~min}$ (final elongation). The PCR products were loaded on $1.5 \%$ agarose $0.5 \times \mathrm{TBE}$ gel and the images of the ethidium bromide stained gels were obtained.

\section{Results}

\section{ERR $\alpha$ and PPAR $\alpha / R X R \alpha$ complex bind to the NRRE-1}

NRRE-1 is a pleiotropic element capable of conferring transcriptional properties by other nuclear receptors including $\operatorname{ERR} \alpha, \operatorname{RAR} \alpha$, or COUP-TFs (Vega \& Kelly 1997 and references therein). NRRE-1 is composed of three potential nuclear receptor half binding site sequences (Fig. 1). Specifically, the $5^{\prime}$ hexamer (site 1, AGGTCA) is in the antisense orientation $8 \mathrm{bp}$ and $14 \mathrm{bp}$ upstream 
of an imperfect sense repeat (site 2 and site 3, GGGTAA and AGGTGA respectively). The architecture of NRRE-1 is unique compared with those of other previously identified nuclear receptor response elements. The receptor hexamer binding sites within this element do not correspond to prototypical receptor response elements such that sequences contributing to receptor function are not predictable from previous reports. Accordingly, we next directly explored the receptor-DNA interactions in detail.

PPAR $\alpha$ and RXR $\alpha$ are known to form a heterodimer complex and this complex was shown to bind to the response element named PPRE (Kliewer et al. 1992, Gearing et al. 1993). We then addressed the question of whether, in addition to $\operatorname{ERR} \alpha$, the PPAR $\alpha / R X R \alpha$ complex could interact with the NRRE-1, although NRRE-1 is clearly distinct from a conventional PPRE. To answer this question, an in vitro gel retardation assay was performed using a radiolabeled NRRE-1 together with in vitro expressed ERR $\alpha$ or PPAR $\alpha / \operatorname{RXR} \alpha$ complex. As shown in Fig. 2A, both ERR $\alpha$ and the PPAR $\alpha$ / RXR $\alpha$ protein complex also bind to the wild-type NRRE-1. As expected, PPAR $\alpha$ or $\operatorname{RXR} \alpha$ alone failed to bind to the DNA (Fig. 2A). To check the specificity of the DNA-protein complex, a molar excess of unlabeled competitors (SFRE, AoxPPRE or OCT) were included (Fig. 2B). SFRE is a known copy of the ERR $\alpha$ binding site from the SF-1 gene (Bonnelye et al. 1997) and AoxPPRE is a known PPAR $\alpha / R X R \alpha$ binding site from the fatty acylCoA oxidase (Kassam et al. 1999). A 50-fold molar excess of specific competitors (SFRE or AoxPPRE) was able to eliminate the DNA-protein complex whereas the same amounts of non-specific competitors (OCT) were unable to do so. These experiments confirmed that both ERR $\alpha$ and PPAR $\alpha / R X R \alpha$ specifically interact with the NRRE-1.

\section{Binding site analysis}

NRRE-1 contains three hexamer binding sequences separated by $8 \mathrm{bp}$ (site 1 and site 2), $14 \mathrm{bp}$ (site 1 and site 3 ) or $0 \mathrm{bp}$ (site 2 and site 3 ) which may be the target sites for nuclear receptor binding as indicated in Fig. 1. Since the nuclear hormone receptor binding to elements with 8 or $14 \mathrm{bp}$ hexamer spacing is currently unknown, we examined the role of these sites by mutational analysis. As a first step in identifying the receptor binding sites in this complex element, systematic mutations were introduced within the potential nuclear receptor half binding sites (M1 through M6, see Fig. 1). As presented in Fig. 3A, mutations in site 1 (M1) had completely lost ERR $\alpha$ binding while mutations in site 3 (M3) had a partial reduction. Mutations in site 2 (M2) had little, if any, effect on ERR $\alpha$ binding. One interesting observation is that site 1 appears to be essential for ERR $\alpha$ binding to NRRE-1, since mutations within site 1 had completely lost the binding activity, irrespective of the presence of an intact site 2 and site 3 (M1, M4, M5). The presence of an intact site 1 with mutated site 2 and/or site 3 (M2, M3 and M6) still had efficient, but lower levels of DNA binding activity in comparison to the wild type (WT). This phenomenon was confirmed by using these mutated as well as WT oligonucleotides as cold competitors (Fig. 3B). The ERR $\alpha$ /NRRE-1dependent DNA-protein complex was strongly inhibited with a 50-fold molar excess of WT, M2 or SFRE while other competitors (M1, M3, M4, M5, M6, OCT) had little effect. These results show the differential importance of these sites for ERR $\alpha$ binding. In order to find out the importance of this phenomenon, we undertook gel retardation assays using WT as well as mutated NRRE-1 (M1 through M6) with increasing amounts of ERR $\alpha$ (Fig. 3C i and ii). The intensity of the ERR $\alpha$-dependent DNA-protein complex was measured and its graphic display is shown in Fig. $3 \mathrm{D} \mathrm{i}$ and ii. These results indicate that site 1 is essential for ERR $\alpha$ binding while site 3 supports ERR $\alpha$ binding only in the presence of an intact site 1. Site 2 appears to be involved in little, if any, ERR $\alpha$ binding.

In the case of PPAR $\alpha / R X R \alpha$, mutations in either site 1 or site 3 (M1 and M3) had reduced DNA binding activities while mutations in site 2 (M2) had little, if any, effect (Fig. 4A). However, mutations in both site 1 and site 3 lost their DNA binding activity (M5) whereas mutations in either site 1 (M4) or site 3 (M6), irrespective of the integrity of site 2, had reduced levels of DNA binding activity. This phenomenon was confirmed by using these mutated as well as WT oligonucleotides as cold competitors (Fig. 4B). The PPAR $\alpha / R X R \alpha$-dependent DNA-protein complex was strongly inhibited with a 50-fold molar excess of WT, M2, or AoxPPRE, while competitors harboring mutations in either site 1 or site 3 (M1, 
A

Proteins:

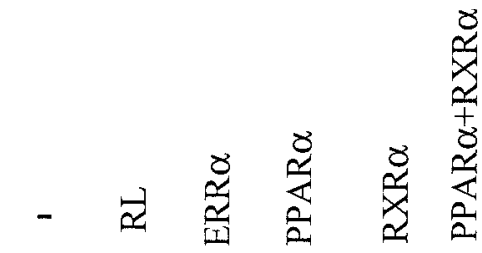

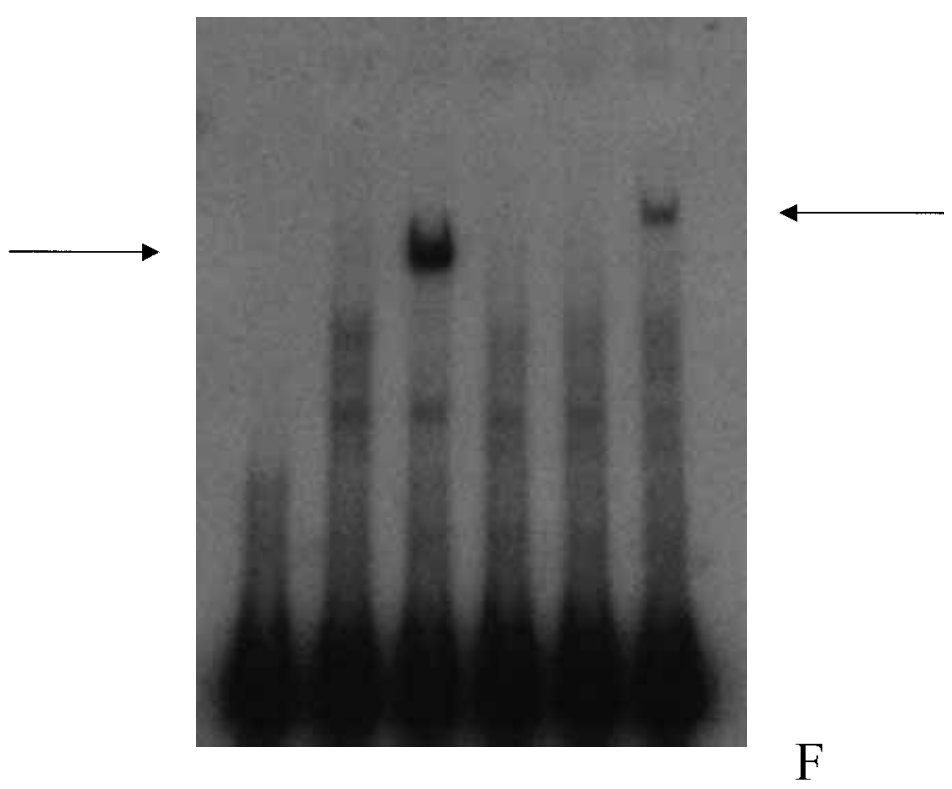

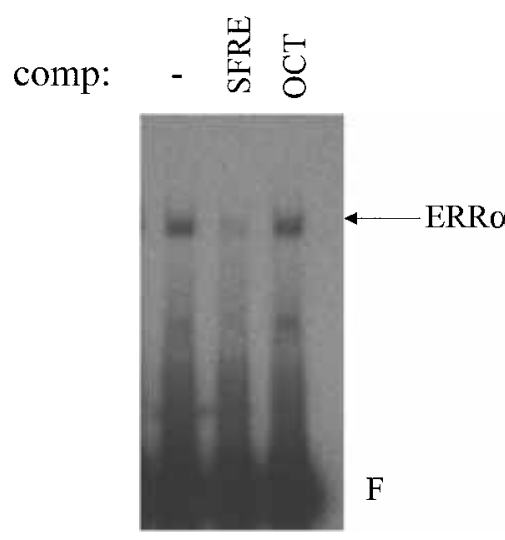

$\operatorname{ERR} \alpha$

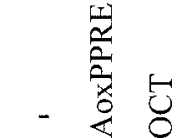

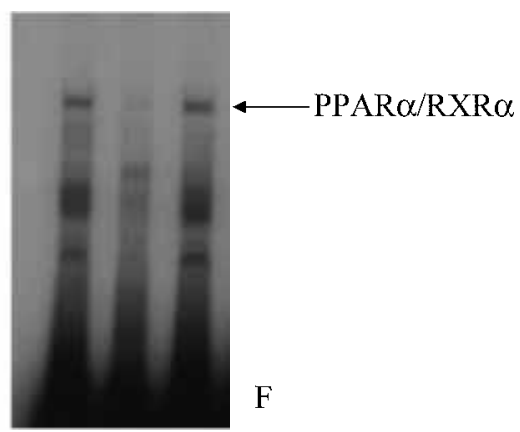

PPAR $\alpha / R X R \alpha$

Figure 2 ERR $\alpha$ and PPAR $\alpha / R X R \alpha$ heterodimer complex can bind to NRRE-1. In vitro transcribed/translated ERR $\alpha$, PPAR $\alpha$, and RXR $\alpha$ were tested for their ability to bind NRRE-1. ${ }^{32} \mathrm{P}$-labeled double-stranded NRRE-1 probes were incubated with $2 \mu \mathrm{l}$ of in vitro transcribed/translated ERR $\alpha$ or PPAR $\alpha / R X R \alpha$ in reticulocyte lysate and the DNA binding was analyzed by gel retardation assay as described in Materials and methods. In some experiments (B), a 50-fold molar excess of unlabeled competitor oligonucleotides (comp) (SFRE, AoxPPRE, or OCT) was added to the reaction. The DNA-protein complex is indicated with an arrow. Free probes are shown at the bottom of the gel $(F)$. 

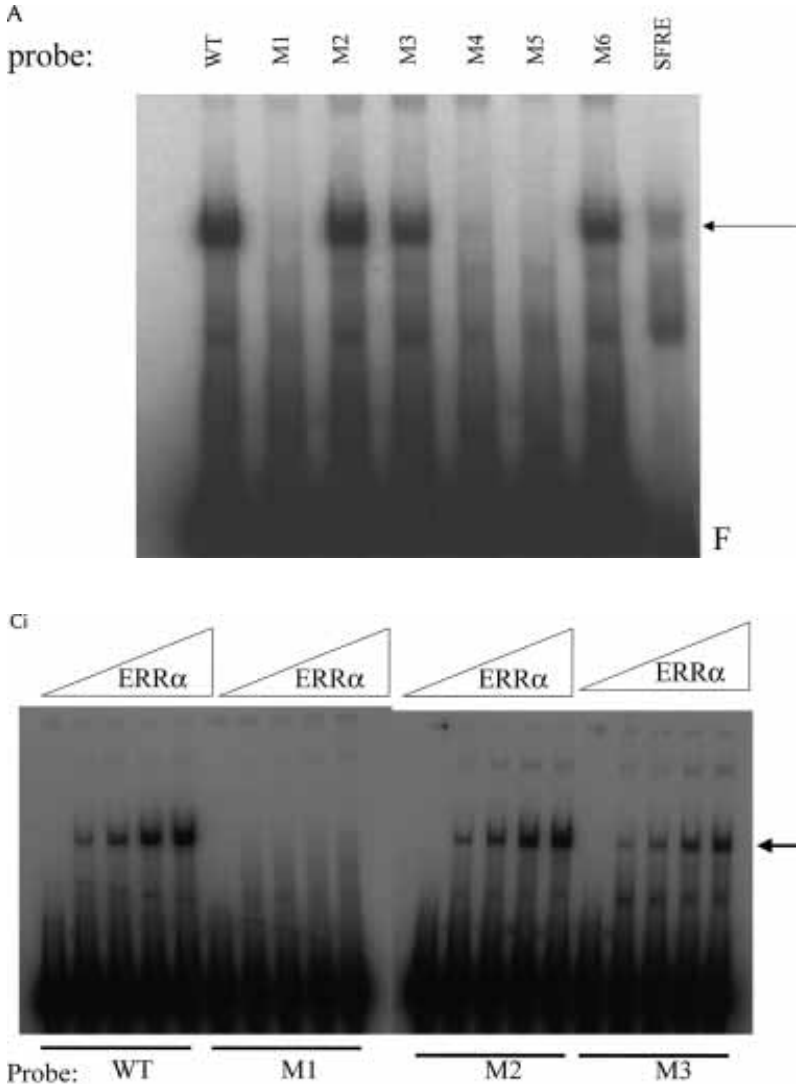

$\mathrm{Di}$

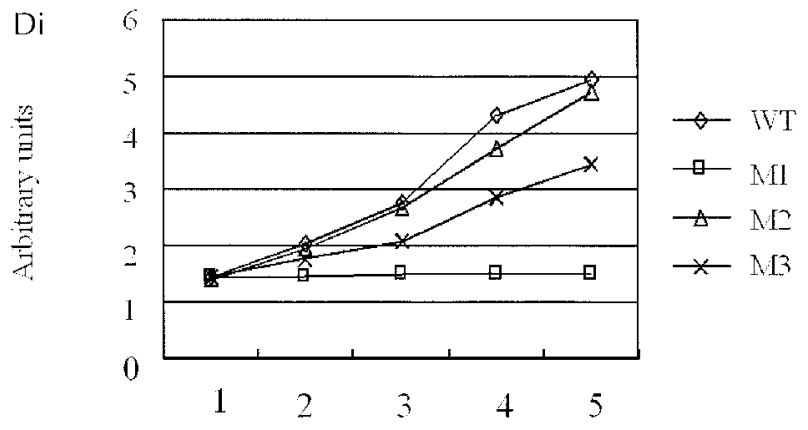

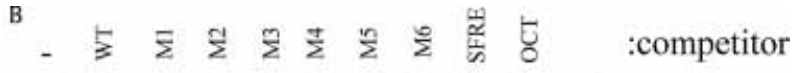
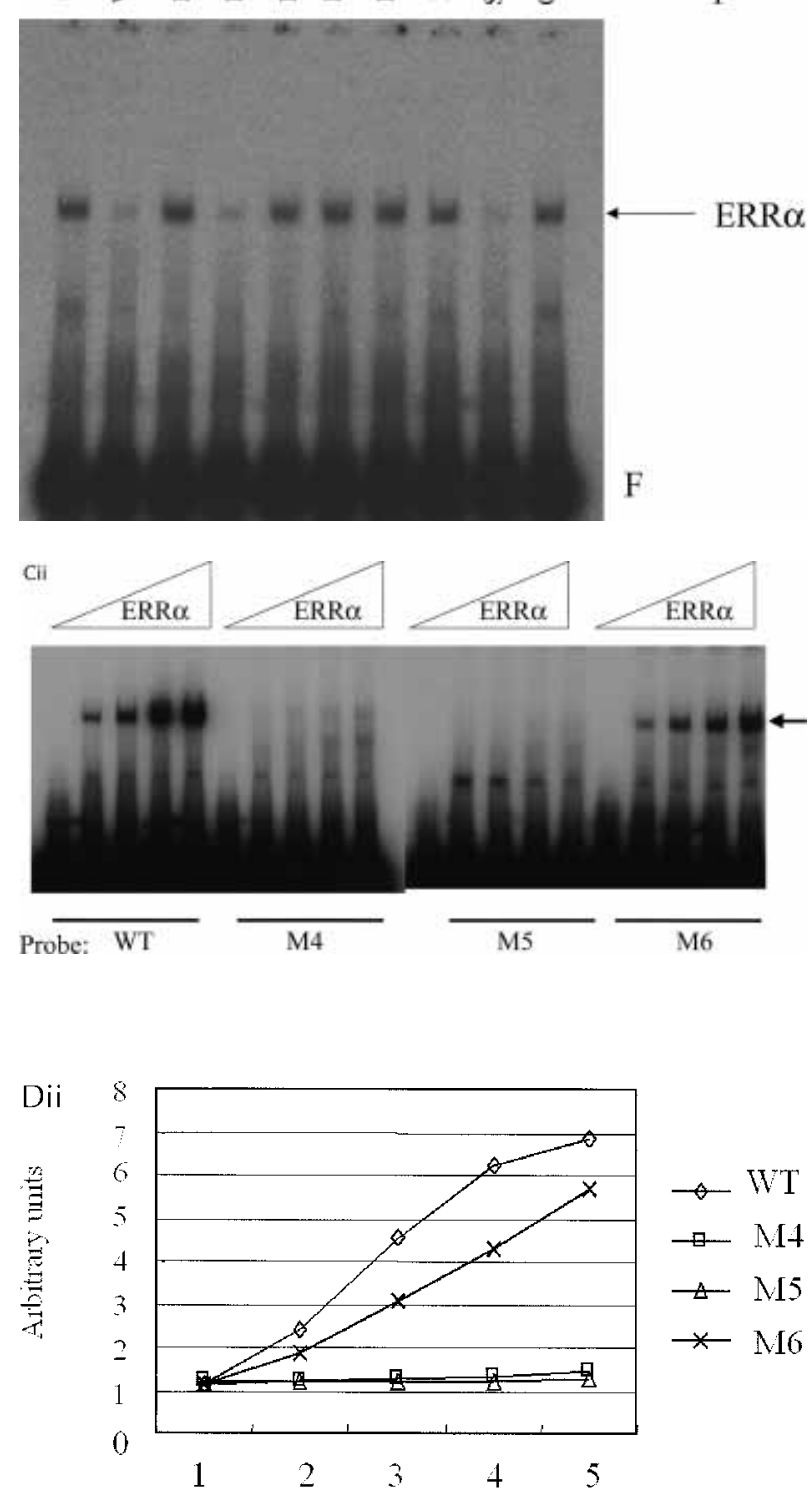

Figure 3 Binding site for ERR $\alpha$. (A) ${ }^{32} \mathrm{P}$-labeled double stranded NRRE-1 WT and mutation probes (M1 through M6) were incubated with $2 \mu \mathrm{l}$ of in vitro transcribed/translated ERR $\alpha$ in reticulocyte lysate and the DNA binding was analyzed by gel retardation assay as described in Materials and methods. Free probes are shown at the bottom of the gel (F). (B) A 50-fold molar excess of unlabeled competitor oligonucleotides (site 1 through 3, OCT) was added to the reaction. Free probes are shown at the bottom of the gel (F). (Ci and ii) Indicated probes (NRRE-1, WT, M1, M2, M3, M4, M5, M6) were incubated with increasing amounts $(0,1,2,4,8 \mu \mathrm{l})$ of in vitro transcribed/translated ERR $\alpha$. ( $\mathrm{Di}$ and ii) The intensity of the DNA-protein complex (shown with an arrow in $\mathrm{C}$ ) is displayed graphically. The $\mathrm{X}$ axis indicates the increasing amounts $(0,1,2,4,8 \mu$ l shown as $1,2,3,4,5)$ of in vitro transcribed/translated ERR $\alpha$. The $Y$ axis indicates the intensities of the signal.

M3, M4, M6) reduced the intensity of the DNA-protein complex. However, M5 (mutations in both site 1 and site 3) had no such effect. These results show the differential importance of three sites for PPAR $\alpha / \mathrm{RXR} \alpha$ binding. In order to further analyze this phenomenon, we undertook gel retardation assays using WT as well as the mutated NRRE-1 (M1 through M6) with increasing 

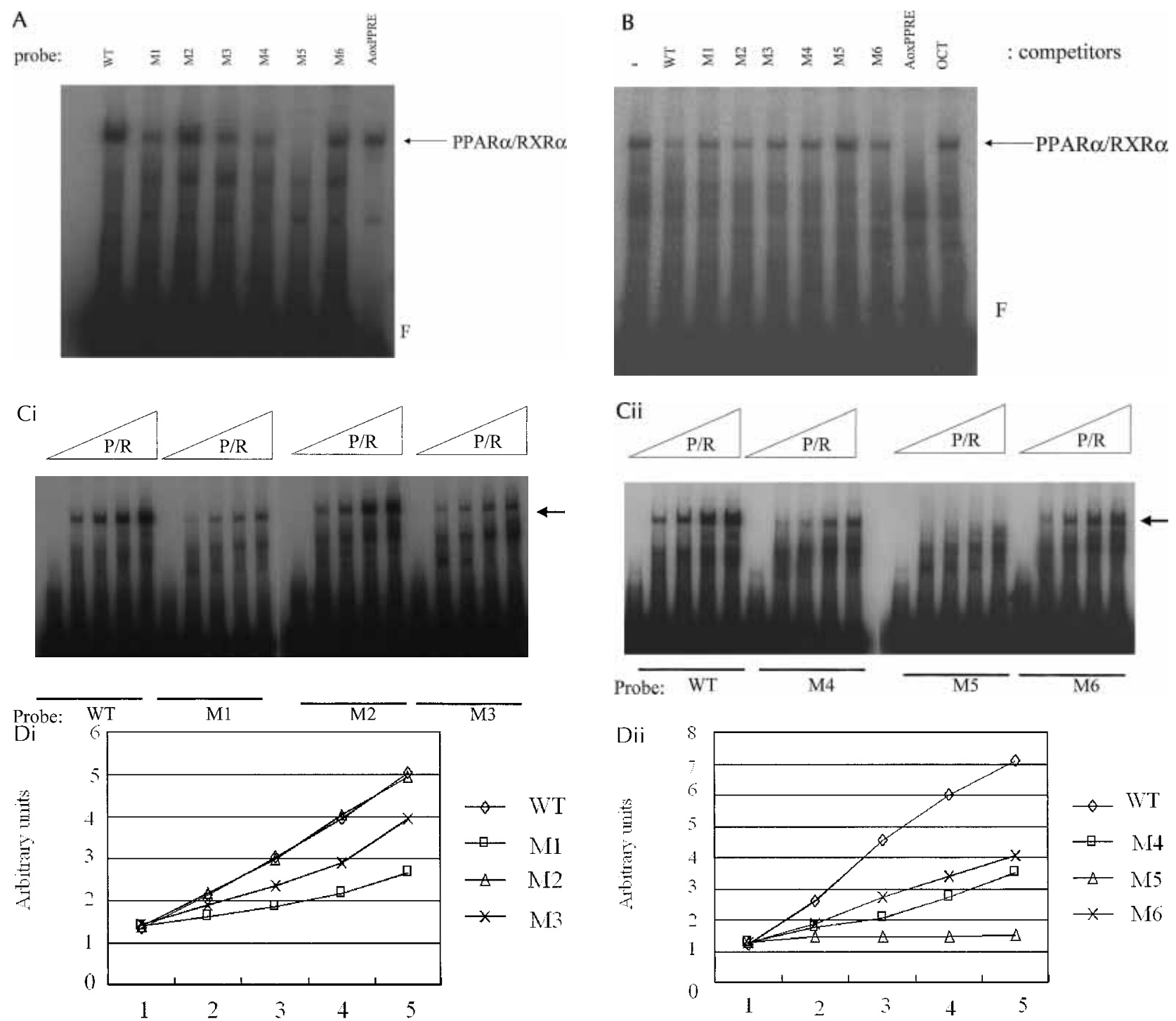

Figure 4 Binding site for PPAR $\alpha / R X R \alpha$. (A) ${ }^{32}$ P-labeled double-stranded NRRE-1 WT and mutation probes (M1 through M6) were incubated with $2 \mu \mathrm{l}$ of in vitro transcribed/translated PPAR $\alpha / R X R \alpha$ in reticulocyte lysate and the DNA binding was analyzed by gel retardation assay as described in Materials and methods. Free probes are shown at the bottom of the gel (F). (B) A 50-fold molar excess of unlabeled competitor oligonucleotides (site 1 through $3, \mathrm{OCT}$ ) was added to the reaction. Free probes are shown at the bottom of the gel $(\mathrm{F})$. (Ci and ii) Indicated probes (NRRE-1 WT, M1, M2, M3, M4, M5, M6) were incubated with increasing amounts $(0,1+1,2+2$, $4+4,8+8 \mu \mathrm{l})$ of in vitro transcribed/translated PPAR $\alpha / R X R \alpha(\mathrm{P} / \mathrm{R})$. (Di and ii) The intensity of the DNA-protein complex (shown with an arrow in $C$ ) is displayed graphically. The $X$ axis indicates the increasing amounts $(0,1+1$, $2+2,4+4,8+8 \mu \mathrm{l}$, shown as $1,2,3,4,5)$ of in vitro transcribed/translated PPAR $\alpha / R X R \alpha$. The $\mathrm{Y}$ axis indicates the intensities of the signal.

amounts of PPAR $\alpha / R X R \alpha$ (Fig. 4G $\mathrm{i}$ and ii). The intensity of PPAR $\alpha / \mathrm{RXR} \alpha$-dependent DNAprotein complex was measured and its graphic display is shown in Fig. 4D i and ii. These results indicate that site 1 and site 3 are involved in PPAR $\alpha / R X R \alpha$ binding while, analogous to the case of ERR $\alpha$, site 2 appears to have little, if any, activity in PPAR $\alpha / \operatorname{RXR} \alpha$ binding. 


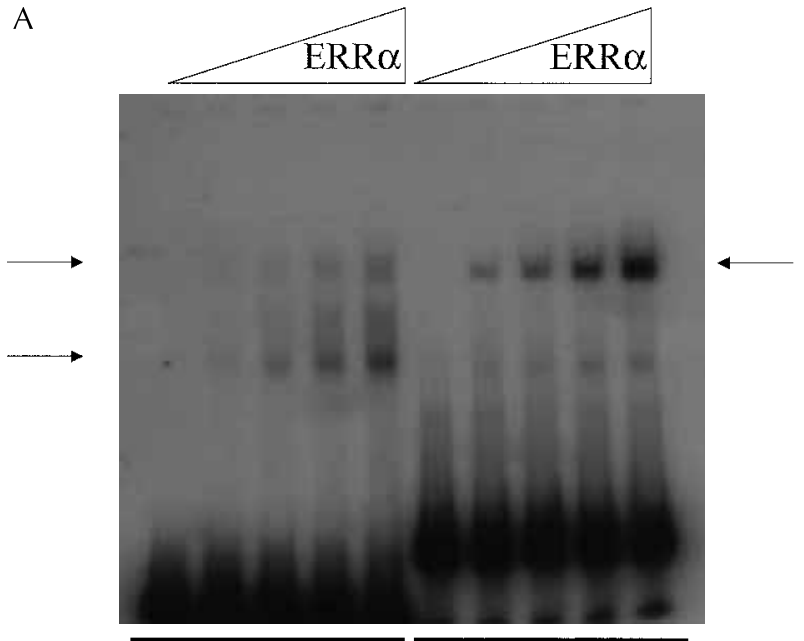

Probe:
B

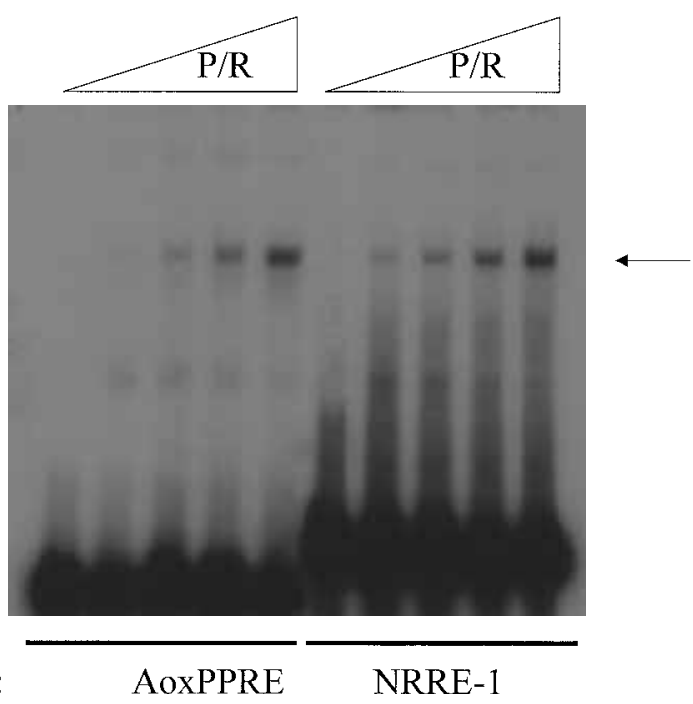

Figure 5 Binding property of ERR $\alpha$ or PPAR $\alpha / R X R \alpha$ to NRRE-1. (A) Radiolabeled SFRE or NRRE-1 was incubated with increasing amounts $(0,1,2,4 \mu \mathrm{l})$ of in vitro transcribed/translated ERR $\alpha$. The DNA-protein complex is indicated with an arrow. Free probes are shown at the bottom (F). (B) Radiolabeled AoxPPRE or NRRE-1 was incubated with increasing amounts $(0,1,2,4 \mu \mathrm{l})$ of in vitro transcribed/translated PPAR $\alpha / R X R \alpha(P / R)$. The DNA-protein complex is indicated with an arrow. Free probes are shown at the bottom $(F)$.

\section{Do ERR $\alpha$ or PPAR $\alpha / R X R \alpha$ bind to NRRE-1 as multimers?}

In the next step, we tested the possibility that ERR $\alpha$ and/or PPAR $\alpha / R X R \alpha$ could bind to the NRRE-1 as multimers. To answer this question, we performed gel retardation assays using SFRE or NRRE-1 together with increasing amounts of $\mathrm{ERR} \alpha$ or PPAR $\alpha / \mathrm{RXR} \alpha$ protein expressed in reticulocyte lysates. As shown in Fig. 5A, the position of the DNA-protein complex was different with SFRE or NRRE-1. Although it is not clear, ERR $\alpha$ appears to bind to this extended half-site as a monomer (Johnston et al. 1997). Thus it is likely that ERR $\alpha$ binds to NRRE-1 as a homodimer or as two independent monomers. In the case of PPAR $\alpha / R X R \alpha$, the position of the DNA-protein complex was similar with both AoxPPRE and NRRE-1 (Fig. 5B). However, the in vivo relevance and significance of this observation are still unanswered and will need more investigations.

\section{Competitive binding between ERR $\alpha$ and PPAR $\alpha / R X R \alpha$}

From the DNA binding analysis using mutations (Figs 3 and 4), it appears that the binding sites for ERR $\alpha$ and PPAR $\alpha / R X R \alpha$ overlap (site 1 and site 3). We then addressed the question of whether they can compete with each other for the same response element or whether they form a high order complex. To answer this question, in vitro translated PPAR $\alpha / R X R \alpha$ was then added in a dosedependent manner to the NRRE-1-ERR $\alpha$ dependent DNA-protein complex. As shown in Fig. 6, the addition of PPAR $\alpha / \operatorname{RXR} \alpha$ could dose-dependently compete with ERR $\alpha$ binding to NRRE-1. This result implies that PPAR $\alpha / R X R \alpha$ can compete with $\operatorname{ERR} \alpha$ for the same response element present in NRRE-1.

\section{ERR $\alpha$ counteracts the PPAR $\alpha / R X R \alpha$-mediated transcriptional activation}

To gain an insight into the cellular significance of the in vitro observation above, we performed transient transfections of HeLa cells with the ERR $\alpha$ and/or PPAR $\alpha / \mathrm{RXR} \alpha$ expression vectors and the CAT reporter gene plasmid containing the NRRE-1 response element upstream of the TK-promoter (NRRE-1/pBLCAT2) or the TKpromoter alone (pBLCAT2). In advance, to certify that ERR $\alpha$ is expressed in this experimental system, we checked its expression after transfection. RNA was prepared and quantitative RT-PGR was performed using ERR $\alpha$ specific primer. As shown in Fig. 7A, transfection of increasing amounts of 


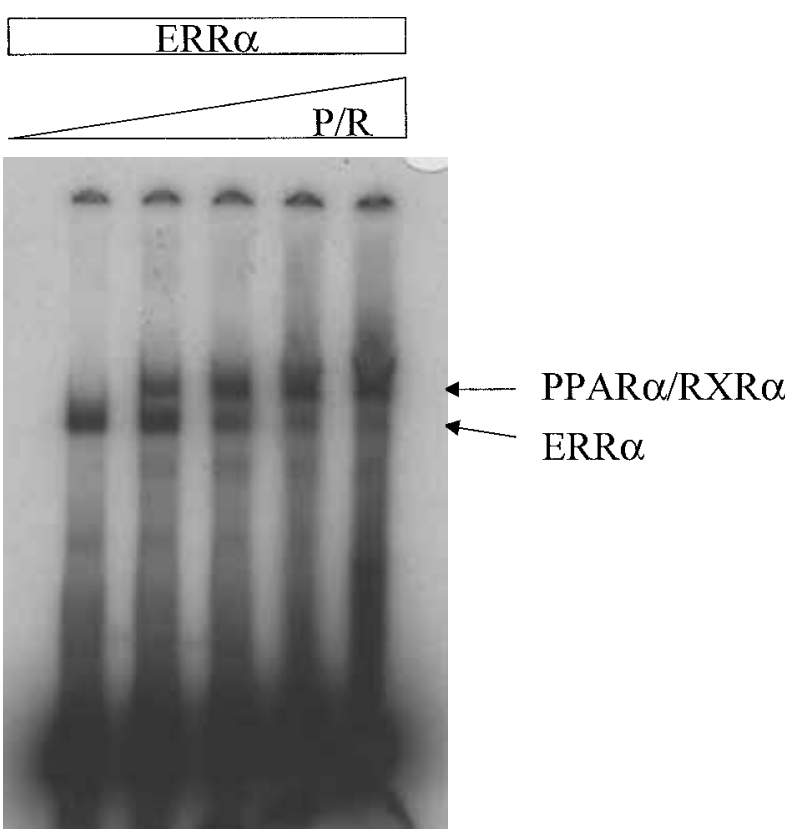

Figure 6 Competition between the PAPR $\alpha / R X R \alpha$ complex and ERR $\alpha$ to NRRE-1. Gel retardation assay was performed using the radiolabeled NRRE-1 probe together with fixed amounts of in vitro translated ERR $\alpha$ $(3 \mu \mathrm{l})$ and increasing amounts of PPAR $\alpha / R X R \alpha$ complex $(0+0,1+1,2+2,3+3,4+4 \mu \mathrm{l})$. Free probes are shown at the bottom $(F)$

ERR $\alpha$ expression vectors did indeed increase its mRNA levels. In contrast to this, expression levels of glyceraldehyde phosphate dehydrogenase (shown as GA; Kutoh et al. 1998) were not influenced by ERR $\alpha$ expression vectors. This pre-experiment showed that $\mathrm{ERR} \alpha$ is indeed expressed in our system.

Transfection of ERR $\alpha$ expression vector slightly increased the TK-promoter activity (Fig. 7B). ERR $\alpha$ had little, if any, effect on the reporter activity driven by NRRE- 1 while PPAR $\alpha / \mathrm{RXR} \alpha$ with its agonist, Wy14,643 (Takahashi \& Kawada 2001), increased the same activity by approximately sevenfold (Fig. 7G). Then, increasing amounts of ERR $\alpha$ expression vectors with fixed amounts of PPAR $\alpha / \mathrm{RXR} \alpha$ dose-dependently suppressed the reporter gene activity driven by PPAR $\alpha / R X R \alpha$ complex with Wy14,643 (Fig. 7D). These results suggest that ERR $\alpha$ counteracts the $\operatorname{PPAR} \alpha / \mathrm{RXR} \alpha$-mediated transcriptional activation within the NRRE-1. Taken together, these in vitro (Fig. 6) and cellular (Fig. 7) experiments suggest that ERR $\alpha$ can compete with $\mathrm{RXR} \alpha / \mathrm{PPAR} \alpha$ for the NRRE-1 and repress the RXR $\alpha / P P A R \alpha-$ mediated transcriptional activity.

There are conflicting data regarding the transcriptional activity of ERR $\alpha$. As mentioned in the Introduction, some groups showed that ERR $\alpha$ is a transcriptional repressor while others reported that it is an activator. Differential corepressor recruitment is one mechanism that could explain why $\operatorname{ERR} \alpha$ can bind its response element without significant transcriptional activities. Thus, we tested the effect of trichostatin A (TSA), a selective inhibitor of histone deacetylase (HDAG) as well as a disruptor of HDAC associated co-repressor complexes (Rosenfeld \& Glass 2001), on the transcriptional repression observed by the expression of ERR $\alpha$. We added TSA in an effort to re-activate the ERR-repressed conditions. However, no consistent data have been obtained (results not shown).

\section{Discussion}

\section{DNA binding properties of ERR $\alpha$ and PPAR $\alpha / R X R \alpha$ complex to the NRRE-1 of the human MCAD gene promoter}

In the first place, we showed that the PPAR $\alpha$ / $\operatorname{RXR} \alpha$ complex as well as ERR $\alpha$ could bind to NRRE-1 which was shown to be essential for high levels of expression of MCAD gene (Vega \& Kelly 1997). The three potential hexamer half-binding sites (core elements) for nuclear receptors were separated by 8,14 and 0 bp respectively. Comparison of the DNA sequences and arrangement of NRRE-1 binding sites with the list of other known naturally occurring and artificial ERR $\alpha$ or PPAR/RXR $\alpha$ response elements (Ijpenberg et al. 1997, Juge-Aubry et al. 1997, Sladek et al. 1997) demonstrates that only site 1 matches the proposed consensus binding sequence AGGTCA, whereas site 2 (GGGTAA) and site 3 (AGGTGA) contain a mismatch in the penultimate residue. The hexamer orientation and spacing requirements for elements conferring ERR $\alpha$ or PPAR $\alpha / \operatorname{RXR} \alpha$ have not been completely established, although the majority of elements are direct repeats. The mutational analysis of the NRRE-1 shown here demonstrated that the active sites for nuclear receptor binding (site 1 and site 3 ) have an everted repeat motif with site 1 separated from site 3 by 14 bp (Figs 3 and 4, site 2 appears to be non-functional in binding to 
A
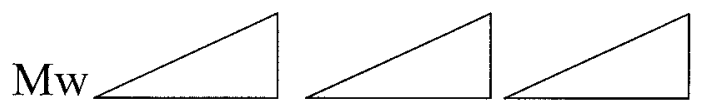

$\mathrm{Mw}$

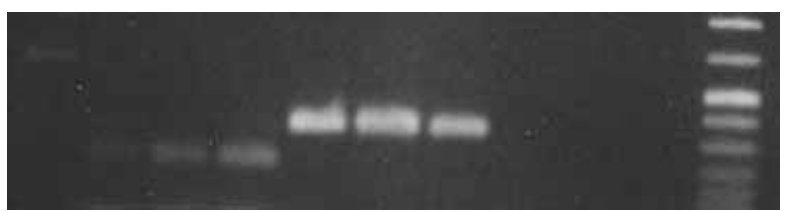

$\operatorname{ERR} \alpha$
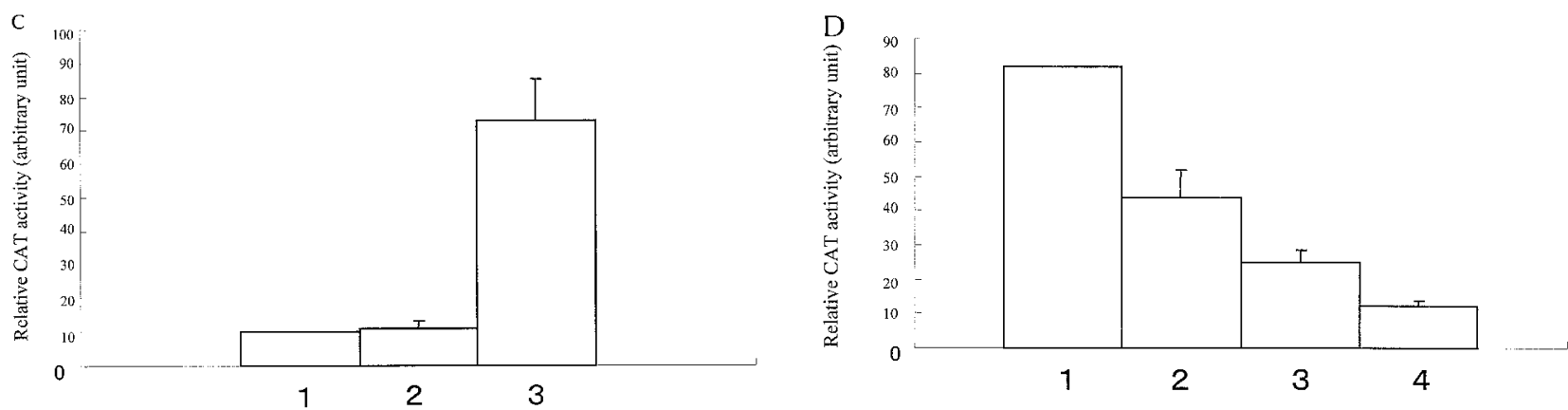

Figure 7 Effect of ERR $\alpha$ on PPAR $\alpha / R X R \alpha$-mediated transcription. Ten micrograms pBLCAT2 reporter gene with or without NRRE-1 before the TK-promoter were co-transfected with $10 \mu \mathrm{g} P P A R \alpha / R X R \alpha$ and increasing amounts $(0,5$, $10,20 \mu \mathrm{g}$ ) of ERR $\alpha$ expression vectors in HeLa cells in the presence of $10 \mu \mathrm{M}$ PPAR $\alpha$ agonist, Wy14,643. One microgram pSV- $\beta$-gal control plasmid was also co-transfected to check the transfection efficiency. After $24 \mathrm{~h}$, the cells were lysed and either RNA was prepared and semi-quantitative RT-PCR was undertaken (A) or CAT activity was calculated by ELISA (B, C and D). The bar graphs represent the mean values with S.E. obtained from four independent experiments. (A) Expression of ERR $\alpha$ after transfection (5, 10, $20 \mu \mathrm{g})$. PCR primers used were ERR $\alpha$ and control GA. Negative controls were taken from RNA without reverse transcriptase (-RT). Mw, molecular weight ladder. (B) Effect of ERR $\alpha$ on the constitutive TK (thymidine kinase) promoter. 1, pBLCAT2; 2, pBLCAT2+10 $\mu \mathrm{g}$ ERR $\alpha$ expression vector. (C) Effect of ERR $\alpha$ on NRRE-1. 1, NRRE-1/pBLCAT2; 2, NRRE-1/pBLCAT2+10 $\mu$ g ERR $\alpha$; 3, NRRE-1/pBLCAT2+10 $\mu \mathrm{g}$ PPAR $\alpha / R X R \alpha$. (D) Effect of ERR $\alpha$ on NRRE-1. 1, NRRE-1/pBLCAT2+0 $\mu \mathrm{g}$ ERR $\alpha$; 2, NRRE-1/pBLCAT2 +5 $\mu \mathrm{g}$ ERR $\alpha ; 3$, NRRE-1/pBLCAT2+10 $\mu \mathrm{g}$ ERR $\alpha ; 4$, NRRE-1/pBLCAT2+20 $\mu \mathrm{g}$ ERR $\alpha$.

ERR $\alpha$ or PPAR $\alpha / R X R \alpha$ ). This binding half-site arrangement (ER14) is novel compared with other previously reported PPREs or ERR-response elements (Ijpenberg et al. 1997, Juge-Aubry et al. 1997, Sladek et al. 1997). Based on the results from gel retardation assays using mutated NRRE-1 (Figs 4 and 5), our conclusions regarding the importance of these hexamer sites are as follows: site 1-ERR $\alpha$ : essential, PPAR $\alpha / R X R \alpha$ : involved; site 2-ERR $\alpha$ : not involved, PPAR $\alpha / \mathrm{RXR} \alpha$ : not involved; site 3ERR $\alpha$ : partially involved only in the presence of intact site 1, PPAR $\alpha / \mathrm{RXR} \alpha$ : involved.

The schematic presentation of this conclusion is illustrated in Fig. 8.
It is of interest that ERR $\alpha$ binds to site 3 only in the presence of an intact site 1, implying a possible dimerization formation with site 1 and site 3 . That dimerization is present on the everted repeat with 14 inverted bp (ER 14), as distinct from dual monomer co-occupation, is evidenced by the fact that site 3 is occupied only in the presence of an intact site 1. Thus, ERR $\alpha$ most probably binds exclusively to site 1 and the dimer binding is necessary for simultaneous occupation of half-sites (site 1 and site 3 ). In the case of the PPAR $\alpha / R X R \alpha$ heterodimer complex, it appears to bind site 1 and site 3, everted repeat with 14-interval bp (ER14). One of the explanations of why PPAR $\alpha / \operatorname{RXR} \alpha$ 


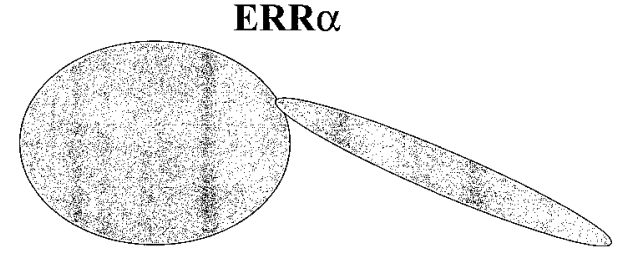

GGGTTTGACCTTTCTCTCCGGGTAAAGGTGAAGG

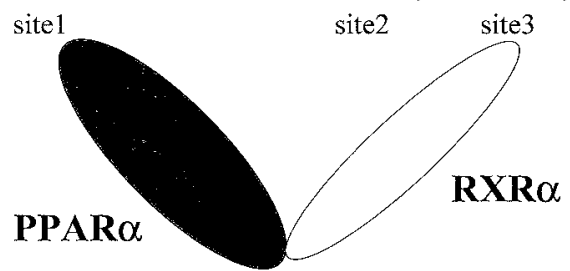

Figure 8 Schematic representation of $E R R \alpha$ and $\mathrm{PPAR} \alpha / \mathrm{RXR} \alpha$ interactions with NRRE-1.

can still bind to NRRE-1, which is mutated either in site 1 or site 3 , is that the binding site requirement of this nuclear receptor complex might be rather permissive. Anyhow, it is rather unusual that heterodimer (PPAR $\alpha / \mathrm{RXR} \alpha)$ or homodimer $(\mathrm{ERR} \alpha)$ receptors interact with such long intervals.

\section{Competitive binding and effect of transcription of ERR $\alpha$ and PPAR $\alpha / R X R \alpha$ within NRRE-1}

Although ERR $\alpha$ and PPAR $\alpha / \operatorname{RXR} \alpha$ may use overlapping but distinct determinants on the NRRE-1, we did not observe a higher order complex containing all three receptors in vitro. Instead, we observed competitive binding between ERR $\alpha$ and RXR $\alpha / P P A R \alpha$ for the same sites within the NRRE-1 (Fig. 6). This observation is reflected in the cellular experiment showing that expression of ERR $\alpha$ can counteract the transcriptional activation by the RXR $\alpha / \mathrm{PPAR} \alpha$ complex (Fig. 7). ERR $\alpha$ may also form inactive and non-binding heterodimers with PPAR $\alpha, \operatorname{RXR} \alpha$ or other nuclear factors, effectively sequestering these receptors and preventing them from forming heterodimers that normally induce transcriptional activation, leading to an overall repression of transcription. However, the latter mechanism is unlikely, since inhibition by ERR $\alpha$ required the integrity of the NRRE-1 (Fig. 7B,C,D). It is possible, in vivo, that one of the receptors may constitute a predominant component of the complex, because these nuclear receptor expression patterns are distinct among different tissues.
Characterization of individual binding profiles may provide clues to the compositions of the heterogeneous complex.

At the same time, isolation and characterization of endogenous nuclear proteins that bind to NRRE-1, apart from the ones that have already been identified (Carter et al. 1994, Vega \& Kelly 1997), will be necessary to fully define this transcriptional regulatory mechanism and to delineate the precise upstream regulatory pathways involved in the control of fatty acid oxidation enzyme expression.

\section{Transcriptional and physiological properties of ERR $\alpha$ on MCAD gene: an hypothesis}

$\mathrm{ERR} \alpha$ was reported to regulate the promoters of lactoferrin (Yang et al. 1996), MCAD (Vega \& Kelly 1997), osteopontin (Bonnelye et al. 1997) or TR $\alpha$ (Vanacker et al. 1998) in transient transfection assays. ERR $\alpha$ generally represses gene transcription in these assays (Sladek et al. 1997) as well as in cell-free systems (Wiley et al. 1993, Johnston et al. 1997), and has also been shown to antagonize the action of GR via an unknown mechanism (Trapp \& Holsboer 1996). The lack of ERR $\alpha$ transcriptional activity may be due to the absence of its cognate ligand. However, under certain conditions, ERR $\alpha$ was reported to activate transcription (Vanacker et al. 1998). These authors (Vanacker et al. 1998) reported that the transcriptional activity observed is dependent on a serum compound that was withdrawn by charcoal treatment. We were not able to reproduce this data of transactivation in HeLa, HepG2 or SK-N-MG cells (results not shown). It may be that ERR $\alpha$ ligand is present in certain serum preparations but not in others. Taken together, it appears that $\operatorname{ERR} \alpha$ can exert pleiotropic transcriptional controls depending on the targeted promoter and on the cell type considered. However, its mechanism remains completely unknown.

NRRE-1 is crucial for MCAD expression in transgenic models (Vega \& Kelly 1997). Transcriptional regulation via NRRE-1 appears to be a net aggregate response manifested, in part, by the availability of ERR $\alpha$ and other factors that bind to NRRE-1, the complexity of response elements and the interplay of ERR $\alpha$ with other nuclear hormone receptors. It can be proposed that ERR $\alpha$ can influence the MCAD expression through 
interaction with these nuclear receptors. Our hypothesis is that ERR $\alpha$ acts as a transcriptional repressor by competing with the $\mathrm{RXR} \alpha / \mathrm{PPAR} \alpha$ complex (or other activators that interact with NRRE-1) for the same sequence within the NRRE-1. Physiological evidence for this model comes from the ERR $\alpha$-deficient mice (Giguere 1999). They are smaller than the wild-type and show decreased fat content throughout their bodies. Probably due to the absence of ERR $\alpha$ that acts as a repressor of the MCAD gene through NRRE-1, other activators (e.g. RXR $\alpha / \operatorname{PPAR} \alpha$ ) could occupy the NRRE-1 and drive out high rates of transcription of MCAD gene, thereby inducing the high rate of $\beta$-oxidation. Our data of this comparative profile demonstrate that this receptor may interact with elements possessing a wide variety of architectures, a phenomenon consistent with the hypothesis that it acts as a general suppressor of many genes. In this hypothesis, the structure of ERR $\alpha$ bound to NRRE-1 or its response element would be relatively permissive for corepressor binding. It is also possible that allosteric effects of the DNA binding site could alter interactions with co-activators or with other DNA-bound transcription factors. Although we failed to show re-activation of the ERR $\alpha$ dependent repression with the addition of TSA, it remains to be determined whether such DNAinduced conformational changes can alter coactivator or co-repressor binding. As yet, the transcriptional regulation of ERR $\alpha$ remains largely unknown, despite the fact that this was the first nuclear orphan receptor identified many years ago (Giguere et al. 1988). Ligands of this receptor may change its transcriptional activity thereby influencing the expression of the target genes by ERR $\alpha$, including the MCAD gene which is an important regulator of the rate of fatty acid $\beta$-oxidation and lipid metabolism. Selective ligands for $\mathrm{ERR} \alpha$ may change the net transcriptional activity of the MCAD gene through NRRE1, thereby influencing lipid metabolism through $\beta$-oxidation. To this end, it is important to monitor the effect of $\operatorname{ERR} \alpha$ on the whole MCAD gene promoter.

\section{Acknowledgements}

We thank Drs Rachubinski and Giguere for the expression plasmids.

\section{References}

Aranda A \& Pascual A 2001 Nuclear hormone receptors and gene expression. Physiological Reviews 81 1269-1304.

Bonnelye E, Vanacker JM, Dittmar T, Begue A, Desbiens X, Denhardt DT, Aubin JE, Laudet V \& Fournier B 1997 The ERR-1 orphan receptor is a transcriptional activator expressed during bone development. Molecular Endocrinology 11 905-916.

Carter ME, Gulick T, Moore DD \& Kelly DP 1994 A pleiotropic element in the medium-chain acyl coenzyme A dehydrogenase gene promoter mediates transcriptional regulation by multiple nuclear receptor transcription factors and defines novel receptor-DNA binding motifs. Molecular and Cellular Biology 14 $4360-4372$.

Edwards DP 1999 Coregulatory proteins in nuclear hormone receptor action. Vitamins and Hormones 55 165-218.

Forman BM \& Evans RM 1995 Nuclear hormone receptors activate direct, inverted, and everted repeats. Annals of the New York Academy of Sciences 761 29-37.

Freedman LP \& Luisi BF 1993 On the mechanism of DNA binding by nuclear hormone receptors: a structural and functional perspective. Fournal of Cellular Biochemistry 51 140-150.

Gay F, Barath P, Desbois-Le Peron C, Metivier R, Le Guevel R, Birse D \& Salbert G 2002 Multiple phosphorylation events control chicken ovalbumin upstream promoter transcription factor I orphan nuclear receptor activity. Molecular Endocrinology 16 1332-1351.

Gearing KL, Gottlicher M, Teboul M, Widmark E \& Gustafsson JA 1993 Interaction of the peroxisome-proliferator-activated receptor and retinoid X receptor. PNAS 90 1440-1444.

Giguere V 1999 Orphan nuclear receptors: from gene to function. Endocrine Reviewes 20 689-725.

Giguere V 2002 To ERR in the estrogen pathway. Trends in Endocrinology and Metabolism 13 220-225.

Giguere V, Yang N, Segui P \& Evans RM 1988 Identification of a new class of steroid hormone receptors. Nature 331 91-94.

Gottlicher M, Heck S \& Herrlich P 1998 Transcriptional cross-talk, the second mode of steroid hormone receptor action. Fournal of Molecular Medicine 76 480-489.

Hsiao PW, Deroo BJ \& Archer TK 2002 Chromatin remodeling and tissue-selective responses of nuclear hormone receptors. Biochemistry and Cell Biology 80 343-351.

Hunter J, Kassam A, Winrow CJ, Rachubinski RA \& Capone JP 1996 Crosstalk between the thyroid hormone and peroxisome proliferator-activated receptors in regulating peroxisome proliferator-responsive genes. Molecular and Cellular Endocrinology $116213-221$.

Ijpenberg A, Jeannin E, Wahli W \& Desvergne B 1997 Polarity and specific sequence requirements of peroxisome proliferatoractivated receptor (PPAR)/retinoid X receptor heterodimer binding to DNA: a functional analysis of the malic enzyme gene PPAR response element. Fournal of Biological Chemistry 272 20108-20117.

Johnston SD, Liu X, Zuo F, Eisenbraun TL, Wiley SR, Kraus RJ \& Mertz JE 1997 Estrogen-related receptor alpha 1 functionally binds as a monomer to extended half-site sequences including ones contained within estrogen-response elements. Molecular Endocrinology $11342-352$

Juge-Aubry C, Pernin A, Favez T, Burger AG, Wahli W, Meier CA \& Desvergne B 1997 DNA binding properties of peroxisome proliferator-activated receptor subtypes on various natural peroxisome proliferator response elements. Importance of the 5'-flanking region. Fournal of Biological Chemistry 272 25252-25259.

Kassam A, Capone JP \& Rachubinski RA 1999 Orphan nuclear hormone receptor RevErbalpha modulates expression from the promoter of the hydratase-dehydrogenase gene by inhibiting 
peroxisome proliferator-activated receptor alpha-dependent transactivation. Fournal of Biological Chemistry 274 22895-22900.

Khorasanizadeh S \& Rastinejad F 2001 Nuclear-receptor interactions on DNA-response elements. Trends in Biochemical Sciences 26 384-390.

Kliewer SA, Umesono K, Noonan DJ, Heyman RA \& Evans RM 1992 Convergence of 9-cis retinoic acid and peroxisome proliferator signalling pathways through heterodimer formation of their receptors. Nature $358771-774$.

Kutoh E, Stromstedt PE \& Poellinger L 1992 Functional interference between the ubiquitous and constitutive octamer transcription factor 1 (OTF-1) and the glucocorticoid receptor by direct protein-protein interaction involving the homeo subdomain of OTF-1. Molecular and Cellular Biology 12 4960-4969.

Kutoh E, Boss O, Levasseur F \& Giacobino JP 1998 Quantification of the full length leptin receptor $(\mathrm{OB}-\mathrm{Rb})$ in human brown and white adipose tissue. Life Sciences 62 445-451.

Kutoh E, Ongenae N, Claeskens A, Verheyen W, Cheyns P, Neefs J \& Kaijen P 2000 A putative white adipose tissue specific nuclear orphan receptor that interacts with the cAMP-response element of the human beta3-adrenergic receptor gene. Molecular and Cellular Endocrinology 165 85-95.

Lee YK \& Moore DD 2002 Dual mechanisms for repression of the monomeric orphan receptor liver receptor homologous protein-1 by the orphan small heterodimer partner. Fournal of Biological Chemistry 277 2463-2467.

Luckow B \& Schutz G 1987 CAT constructions with multiple unique restriction sites for the functional analysis of eukaryotic promoters and regulatory elements. Nucleic Acids Research 155490.

Mangelsdorf DJ, Thummel C, Beato M, Herrlich P, Schutz G, Umesono K, Blumberg B, Kastner P, Mark M, Chambon P et al. 1995 The nuclear receptor superfamily: the second decade. Cell 15 835-839.

Miyata KS, Zhang B, Marcus SL, Capone JP \& Rachubinski RA 1993 Chicken ovalbumin upstream promoter transcription factor (COUP-TF) binds to a peroxisome proliferator-responsive element and antagonizes peroxisome proliferator-mediated signaling. Fournal of Biological Chemistry 268 19169-19172.

Miyata KS, McCaw SE, Patel HV, Rachubinski RA \& Capone JP 1996 The orphan nuclear hormone receptor LXR alpha interacts with the peroxisome proliferator-activated receptor and inhibits peroxisome proliferator signaling. Fournal of Biological Chemistry 19 9189-9192.

Pettersson K, Svensson K, Mattsson R, Carlsson B, Ohlsson R \& Berkenstam A 1996 Expression of a novel member of estrogen response element-binding nuclear receptors is restricted to the early stages of chorion formation during mouse embryogenesis. Mechanisms of Development 54 211-223.

Polak M 1997 New data on nuclear hormone receptor cofactors suggest a control of transcriptional repression by hormonedependent chromatin remodelling. European Fournal of Endocrinology $137455-456$.
Robyr D, Wolffe AP \& Wahli W 2000 Nuclear hormone receptor coregulators in action: diversity for shared tasks. Molecular Endocrinology 14 329-347.

Rosenfeld MG \& Glass CK 2001 Coregulator codes of transcriptional regulation by nuclear receptors. Fournal of Biological Chemistry 276 36865-36868.

Sambrook J, Fritsch EF \& Maniatis T 1989 Molecular Cloning: A Laboratory Manual. New York: Cold Spring Harbor Laboratory Press.

Sladek R, Bader JA \& Giguere V 1997 The orphan nuclear receptor estrogen-related receptor alpha is a transcriptional regulator of the human medium-chain acyl coenzyme A dehydrogenase gene. Molecular and Cellular Biology 17 5400-5409.

Takahashi N \& Kawada T 2001 Physiological and pharmacological function of PPARs. Fapanese Fournal of Pharmacology 117 319-327.

Trapp T \& Holsboer F 1996 Nuclear orphan receptor as a repressor of glucocorticoid receptor transcriptional activity. Fournal of Biological Chemistry 271 9879-9882.

Vanacker JM, Delmarre C, Guo X \& Laudet V 1998 Activation of the osteopontin promoter by the orphan nuclear receptor estrogen receptor related alpha. Cell Growth and Differentiation 9 1007-1014.

Vanacker JM, Pettersson K, Gustafsson JA \& Laudet V 1999 Transcriptional targets shared by estrogen receptor-related receptors (ERRs) and estrogen receptor (ER) alpha, but not by ERbeta. EMBO Fournal 18 4270-4279.

Vega RB \& Kelly DP 1997 A role for estrogen-related receptor alpha in the control of mitochondrial fatty acid beta-oxidation during brown adipocyte differentiation. Fournal of Biological Chemistry 272 31693-31699.

Wiley SR, Kraus RJ, Zuo F, Murray EE, Loritz K \& Mertz JE 1993 SV40 early-to-late switch involves titration of cellular transcriptional repressors. Genes and Development 7 2206-2219.

Willson TM \& Moore JT 2002 Genomics versus orphan nuclear receptors-a half-time report. Molecular Endocrinology 16 1135-1144.

Winrow CJ, Marcus SL, Miyata KS, Zhang B, Capone JP \& Rachubinski RA 1994 Transactivation of the peroxisome proliferator-activated receptor is differentially modulated by hepatocyte nuclear factor-4. Gene Expression 4 53-62.

Winrow CJ, Capone JP \& Rachubinski RA 1998 Cross-talk between orphan nuclear hormone receptor RZRalpha and peroxisome proliferator-activated receptor alpha in regulation of the peroxisomal hydratase-dehydrogenase gene. Fournal of Biological Chemistry 273 31442-31448.

Yang N, Shigeta H, Shi H \& Teng CT 1996 Estrogen-related receptor, hERR1, modulates estrogen receptor-mediated response of human lactoferrin gene promoter. Fournal of Biological Chemistry $2715795-5804$.

\section{Received in final form 5 February 2003 Accepted 2 April 2003}

